\title{
THE IMPACT OF FINANCIAL LEVERAGE ON A COMPANY'S MARKET VALUATION
}

\author{
Artur Zimny, Assistant Professor, Ph.D. \\ Faculty of Economics and Sociology, University of Lodz
}

iD https://orcid.org/0000-0002-6658-952X

\begin{abstract}
The purpose of the article is to examine the impact of leverage on the market valuation of companies. The article verifies two hypotheses: 1 . the degree of leverage is an important factor that impacts the market valuation of companies; 2 . for companies with a high level of leverage, the impact of this leverage on their valuation is negative, and for companies with a low level of leverage, the impact is positive.

The methodology of the study includes a critical literature review and empirical research based on correlation and regression analysis, including univariate and multivariate regression. The analysis covered quarterly data of ten energy companies listed on the Warsaw Stock Exchange. An important component of the research was classifying those companies into several groups, depending on their level of debt ratio in relation to the industry median debt ratio.

The results of the research: The literature review did not provide an unequivocal conclusion to the problem. The empirical analysis did not give grounds to reject the first hypothesis; however, the second one was rejected. The research showed positive correlation and regression coefficients between the debt ratio and the price to book value ratio for highly leveraged companies and negative ones for companies with a low level of debt. The results are surprisingly contrary to the expectations based on theoretical premises.
\end{abstract}

Keywords: financial leverage, capital structure, company financing, company valuation.

JEL Class: D25, G32. 


\section{INTRODUCTION}

The ability to accurately assess the value of companies is crucial for making the right investment decisions on the capital market. A company's value is influenced by many factors that determine its effectiveness, as well as the risk to which it is exposed. Such factors include the financing structure, i.e., the degree of liabilities, which is referred to as financial leverage. The significance and direction of the impact of this leverage on the valuation of companies (or on the returns on their shares) have been the subject of research. However, the results are not fully consistent, which may be due to differences in the assumptions made by the authors. The purpose of this article is to analyze these assumptions and to present research that considers the conclusions of this analysis.

\section{LITERATURE REVIEW}

The early research of Modigliani and Miller, starting with the paper concerning the cost of capital [Modigliani and Miller 1958], is one of the first works that deal with the importance of financial leverage for a company's efficiency. Their research showed that a company's financial structure does not affect its market value; in other words, the degree of debt capital is neutral for the company's valuation by the capital market. However, these early studies relied on a number of strong assumptions, which were later revoked, thus challenging the claim that there is no relationship between the degree of leverage and the value of the company. It also provoked questions about the existence of the optimal capital structure, i.e., one that maximizes value for the company's owners.

Hatfield et al. [1994] refer to research that claims that the optimal capital structure (debt to equity ratio) exists and is strongly related to the average capital structure of the entire industry. It suggests that when companies that issue debt move toward the industry average from below, the market should react more positively than when the company is moving away from the industry average. But their empirical study did not confirm this relationship - they concluded that the market does not appear to consider the relationship between a firm's leverage ratio and the industry's leverage ratio to be important. It should be noted, however, that in the case of companies whose debt before the new debt issuance was higher than the industry average, the issuance of new debt caused a small but statistically significant negative market reaction in the period from 2 to 90 days after the issue.

Hodgson and Stevenson-Clarke [2000] also referred to the concept of the optimal capital structure, discussing the premises of the financial leverage impact on a company's valuation. The first premise suggests a negative impact, as increasing the share of debt in financing a company increases the business's 
financial risk. The second indicates a positive impact, as the financial leverage lowers the cost of capital and proves the managers' optimism. The third, which is a synthesis of the first two, is the conviction that there is an optimal level of debt, above which the negative effect related to the risk level outweighs the positive effect that results from the relative „cheapness” of the debt. The fourth option is the classic approach from the theses of Miller and Modigliani, which assumes that the degree of leverage is neutral for the valuation of the company.

Hodgson and Stevenson-Clarke seem to support the thesis about the optimal debt level, and they take it into account in their empirical study, treating the average level of leverage in the industry as the approximation of the optimal structure of capital for this industry. Their study focused on the importance of leverage in analyzing the impact of the company's profits (and, alternatively, its cash flows) on the return on shares; in other words: what is the relevance of the leverage for the quality of the models that explain the impact of profits or cash flows on the rates of return on shares. They conclude that the relative degree of leverage significantly impacts the importance of profit and cash flow valuation; strong leverage affects the relationship between stock prices, book profits, and cash flows.

Another important observation is presented by Nissim and Penman [2003]. They noted that the standard measure of leverage is total liabilities to equity, but the „total liabilities" category is not homogeneous. It consists of financial liabilities (such as bank loans or bonds issued) and operating liabilities. And the operating liabilities can be further divided into contractual liabilities (such as trade payables, pension liabilities) and estimated liabilities (such as deferred revenues or accrued expenses). In their study, Nissim and Penman found that operating and financing liabilities imply different profitability and are priced differently in the stock market. For a given total leverage from both sources, firms with higher leverage from operations have (on average) higher price to book ratios. This means, inter alia, that when examining the impact of leverage on the valuation of companies, the definition of leverage (debt) should not be limited only to financial liabilities.

The problem of risk as a factor that differentiates the influence of leverage on the rates of return on a company's shares has been presented differently by Muradoglu and Sivaprasad [2008]. They examined this impact separately for different risk classes, by which they understood nine main industries. The research results showed that belonging to a given risk class (industry) has a significant impact, both on the strength and the direction (the sign of the coefficient) of the relationship between the degree of leverage and the rates of return on shares. The rates of return on stocks were higher for higher levels of leverage in one of these classes, referred to as „utilities”, while for companies in other classes 
(industries), the relationship was negative (i.e., an increase in the degree of leverage resulted in decreasing rates of return).

Adding to the study additional explanatory variables (apart from leverage) that represent idiosyncratic risk increased the explanatory power of the model, but the influence of the leverage on the rates of return was still negative. Their approach, in which specific industries are treated as risk classes, is debatable. Each industry undoubtedly includes companies with significantly higher and lower levels of financial leverage, so treating a given industry as a homogeneous risk class seems to be unjustified.

Using all food and beverage manufacturing firms listed on the Indonesian Stock Exchange, Marlina [2013] tested the influence of fundamental factors (earning per share, return on equity, debt to equity ratio, and size) on the price to book value ratio. The results of the regression analysis showed that the debt to equity ratio was among the variables that showed a positive and significant impact on the price to book value ratio.

The study by Gill and Obradovich [2012] examined the impact of several factors (board size, CEO duality, audit committee, financial leverage, company size, return on assets, and internal resources) on the value of American companies listed on the New York Stock Exchange. The results of the regression study showed that the degree of leverage was among the factors that positively impact companies' value. The impact of the examined factors on the value of firms was different for manufacturing companies and for service companies, but in both cases, the impact of the financial leverage was positive.

Similar conclusions come from other studies. In one of them [Rizqia et al. 2013], the authors analyzed the impact of several factors, including financial leverage, on the dividend policy, and on the value of companies. The study covered manufacturing companies listed on the Indonesian Stock Exchange. The study showed a positive and statistically significant impact of financial leverage on the value of companies. Another study [Dita and Murtaqi 2014], also based on companies listed on the Indonesian Stock Exchange, but operating in a different industry (namely, consumer goods), examined the impact of several factors, including debt to equity ratio, on the returns on the stocks of those companies. Again, the impact of financial leverage (represented by debt to equity ratio) on the increase of companies' valuation (which results in the rate of return on shares) proved to be positive and statistically significant.

Contrary results are shown in the study by Acheampong et al. [2014], which analyzed the impact of financial leverage and company size on the rates of return on shares of selected companies from the manufacturing sector listed on the Ghana Stock Exchange. Their study demonstrated a negative and significant relationship between leverage and stock returns when the overall industrial data was used; however, at the individual firm level, the relationship 
was not stable. For four out of the five selected companies, the impact was negative; for the fifth one, it was positive.

However, in the study by Adenugba et al. [2016], which examined only the impact of financial leverage on company's value (and based on data from five manufacturing companies from the Nigerian Stock Exchange), the impact proved to be significant and positive. Singh and Bansal [2016] examined the impact of leverage (and other factors) on a firm's financial performance and its valuation. The study covered 58 Fast Moving Consumer Goods (FMCG) companies listed on the National Stock Exchange and Bombay Stock Exchange in India. The results showed that leverage has a significant negative impact on a firm's valuation. Another study [Pandya 2016] is based on data from 197 companies classified as Group A companies listed on the Bombay Stock Exchange. It examines the impact of leverage, expressed as the three different measures (ratios), on the market value added. Univariately, all three measures (namely, debt to equity ratio, debt ratio, and interest cover) proved to be statistically significant in explaining the variation in the market value added of the sample companies. However, when taken together (in multiple regression), only interest cover was found to be statistically significant.

The latest research does not provide an unequivocal solution to the analyzed problem. Hirdinis [2019] presented the examination of the effect of capital structure and a firm size on a firm's value, moderated by profitability. The study was based on the sample of seven companies of the mining sector listed on the Indonesia Stock Exchange. He concluded that capital structure has a positive effect on a firm's value and that the profitability is not able to mediate the influence between capital structure and a firm value.

Ibrahim and Isiaka [2020] examined the effect of financial leverage (long term debt to equity ratio) on a firm's value (Tobin's q ratio) with evidence from a sample of 18 selected companies quoted on the Nigerian Stock Exchange. Other variables were utilized as control variables (pairwise correlation). The regression results showed that financial leverage has a significantly negative effect on a firm's value while the result of the pairwise correlation showed that there is no significant linear relationship between leverage and a firm's value. Financial leverage has proven to be a weak predictor of a firm's value.

PeiZhi and Ramzan [2020] focused their study primarily on exploring the influence of corporate governance structure and the capital structure on firms' market-oriented and accounting-based performance. The study covered 45 selected firms listed on the Pakistan Stock Exchange. The findings showed that the governance structure based on diverse expert members accelerates its performance. It was also found that the leverage ratio improves accounting performance, but it has a downward and significant impact on the share prices of listed firms. 
Another research [Lestari et al. 2020] covered all companies listed on the Indonesia Stock Exchange. The subject of the study was the impact of a firm size, leverage (proxy: debt-equity ratio) and profitability on the firm's value (reflected through P/BV ratio). Results showed that leverage has a negative and significant effect on a firm's value. However, the authors indicated that the average value of leverage every year was quite high and experienced rises and falls. A good ratio occured when debt and capital were balanced.

The paper of Jao et al. [2020] presented the analysis of the impact of earning persistence, financial leverage and foreign ownership on corporate reputation and corporate value on non-financial companies listed on the Indonesia Stock Exchange. The authors concluded, inter alia, that financial leverage does not have a significant impact either on the company's value or on the company's reputation.

Research on this problem for the Polish market is difficult to find. There are papers analyzing the impact of financial leverage on a company's performance, but only in book value terms (e.g. impact on profitability or liquidity), while this paper focuses on the impact on company's market valuation. This approach was found only in [Łukasik and Naczyński 2015], who examined the impact of a number of explanatory variables on the dependent variable defined as the market value (capitalization) of companies. The research covered 286 companies listed on the Warsaw Stock Exchange. The multivariate regression analysis showed that the degree of financial leverage (reflected by financial debt to equity ratio) is negatively correlated with the company's value. The authors noted a relatively low level of debt ratios, indicating that Polish companies are cautious in using debt financing.

Summarizing, the literature review does not provide an unequivocal conclusion about the impact of financial leverage on a company's valuation. In general, the studies show that this impact is statistically significant. However, the direction of the impact in some studies proved to be positive (an increase in leverage is accompanied by an increase in the company's value), and in other studies it was negative (a company's value decreases with the increase of leverage). The review of the research also makes it possible to state that the relationship between leverage and a company's valuation is influenced by:

- belonging to a given industry; some studies [Hodgson and StevensonClarke 2000; Muradoglu and Sivaprasad 2008; Gill and Obradovich 2012] indicated it as a differentiating factor, while others limited the scope of companies covered by the study to only one industry;

- the level of leverage in relation to the optimal capital structure; Hatfield et al. [1994] and Hodgson and Stevenson-Clarke [2000] indicated this as an important premise, suggesting that the impact of leverage on a company's valuation may not be stable - it can change (e.g., from positive to negative) with the increase of the level of leverage; surprisingly, other authors did not consider 
this aspect, while it may be the main reason for the inconsistency of the research results; only two studies indirectly referred to this problem, mentioning that in the entire sample the average debt level was relatively high [Lestari et al. 2020] or relatively low [Łukasik and Naczyński 2015], which may suggest that in those particular studies the influence of one of the two mechanisms of impact (positive or negative) strongly outweighs the other one for the entire sample;

- factors other than leverage that influence the company's valuation; the research presented in the literature review was often based on a multivariate regression analysis that considered the simultaneous influence of several factors on the endogenous variable.

Omitting or treating differently the factors mentioned here that may affect the nature of the relationship between financial leverage and the valuation of companies may explain the discrepancy in the research results obtained by various authors. These conclusions were considered when designing this study.

\section{HYPOTHESES AND RESEARCH METHODOLOGY}

Based on the conclusions from the literature analysis, the following two hypotheses were tested:

\section{Hypothesis 1:}

The degree of leverage is an important factor that impacts the market valuation of companies.

\section{Hypothesis 2:}

For companies with a high level of leverage, the impact of this leverage on their valuation is negative, and for companies with a low level of leverage, the impact is positive.

Correlation and regression analysis were used to verify the hypotheses. The degree of financial leverage, represented in the research by the debt ratio (total liabilities to total assets), is the exogenous variable, and the market valuation of the company, represented in the research by the price to book value ratio, is the endogenous variable. Financial leverage gives the company the potential to increase profitability, but it also results in a degree of financial risk; these two phenomena should translate into the value of the surplus (or deficit) of the market valuation of the company's shares in relation to its book value. Therefore, it was concluded that the price to book value ratio would be the most appropriate measure here. 
As noted in the literature review, the relationship between financial leverage and a company's valuation may be influenced by belonging to a given industry and by the level of leverage in relation to the optimal capital structure. Therefore it was decided to limit the research to only one industry and to take the company's leverage deviation from the optimal industry leverage level as a differentiating factor in the analysis. In this study, the optimal capital structure is approximated by the median debt ratio for this group of companies, as suggested by Hodgson and Stevenson-Clarke [2000].

As mentioned above, increasing the scale of a company's financing with liabilities has two effects: beneficial, related to increasing the profitability potential (which is the essence of financial leverage), and disadvantageous, related to increasing financial risk (e.g., the risk of insolvency). It is assumed that for companies maintaining a debt level below the industry optimum the positive effect outweighs the negative one. In that case, the increase of debt, which causes the capital structure to evolve closer to the optimum, should be favorably perceived by investors, and thus it should result in an increase in the valuation of the company's shares (i.e., an increase in the price to book value ratio).

By contrast, for companies that maintain a level of debt higher than the optimum, the assumption is that the negative (risk-related) effect outweighs the positive one (related to the profitability potential). In that case, increasing the debt level further should be negatively perceived by investors and lead to a drop in market valuation of shares (i.e., to a decrease in the price to book value ratio).

The latter mechanism also applies to companies with an optimal debt level. Any change in this level means a move away from the optimum, which should result in a decrease in the valuation of shares, regardless of whether the company is changing its debt level above the optimum (when investors negatively perceive the risk increase) or below (then investors' negative perceptions result from limiting the potential for profitability).

In terms of statistical analysis, the described mechanism means that for companies with a debt level below the industry median, a positive correlation/regression relationship should be expected, while for companies with a debt level equal or higher than the industry median, the expected correlation/regression relationship should be negative.

This research covers the energy industry. There are 11 energy companies listed on the Warsaw Stock Exchange, which are presented in Table 1. 
Table 1. Energy companies listed on the Warsaw Stock Exchange

\begin{tabular}{|c|c|c|c|c|}
\hline Company name & $\begin{array}{c}\text { Name } \\
\text { abbrev. }\end{array}$ & $\begin{array}{c}\text { Financial } \\
\text { report } \\
\text { period }\end{array}$ & $\begin{array}{c}\text { Book value of total } \\
\text { assets as in the } \\
\text { financial report } \\
\text { (million PLN) }\end{array}$ & $\begin{array}{c}\text { Market } \\
\text { capitalization as } \\
\text { of July 18, 2020 } \\
\text { (million PLN) }\end{array}$ \\
\hline CEZ a.s. & CEZ & $2020 / \mathrm{Q} 1$ & 130,435 & 43,039 \\
\hline $\begin{array}{c}\text { PGE Polska Grupa } \\
\text { Energetyczna SA }\end{array}$ & PGE & $2020 / \mathrm{Q} 1$ & 80,970 & 12,501 \\
\hline Tauron Polska Energia SA & TPE & $2020 / \mathrm{Q} 1$ & 42,941 & 4,364 \\
\hline Enea SA & ENA & $2020 / \mathrm{Q} 1$ & 31,895 & 3,194 \\
\hline Energa SA & ENG & $2020 / \mathrm{Q} 1$ & 21,543 & 3,437 \\
\hline Polenergia SA & PEP & $2020 / \mathrm{Q} 1$ & 2,657 & 2,013 \\
\hline $\begin{array}{c}\text { Zespół Elektrowni Pątnów- } \\
\text { Adamów-Konin SA }\end{array}$ & ZEP & $2020 / \mathrm{Q} 1$ & 3,317 & 477 \\
\hline $\begin{array}{c}\text { Zespół Elektrociepłowni } \\
\text { Wrocławskich Kogeneracja SA }\end{array}$ & KGN & $2020 / \mathrm{Q} 1$ & 2,838 & 574 \\
\hline Elektrociepłownia Będzin SA & BDZ & $2019 / \mathrm{Q} 4$ & 465 & 34 \\
\hline Inter Rao Lietuva A.B. & IRL & $2020 / \mathrm{Q} 1$ & 210 & 316 \\
\hline ML System SA & MLS & $2020 / \mathrm{Q} 1$ & 233 & 333 \\
\hline
\end{tabular}

Source: www1 and www2, access 18.07.2020.

ML System SA was excluded from the research because its listing on the stock exchange was too short.

The financial data for calculating the debt ratios and ROA ratios were obtained from the Biznesradar database [www1, access 18-31.07.2020]. The price to book value ratio data (for the companies and for the whole market, referred to as the WIG P/BV ratio) was taken from the Stooq database [www2, access 18.07.2020]. Quarterly data for Q3 2013-Q2 2020 were analyzed, which constitutes a time series of 27 quarters for each company.

As the financial reports are published after the day they are drawn up for, the analysis assumes that the level of debt at the end of a given quarter impacts the price to book value ratio in the next quarter. The P/BV ratio values for the quarters were calculated as averages of daily values.

The classification of companies according to their debt level in relation to the industry median debt level was based on the analysis of the deviations of these values (see Table 2), supported by visualization of data in the form of a chart (see Chart 1). Seven companies can be quite clearly classified as having a debt level higher, close to, or lower than the industry median throughout the whole analyzed period. In three cases, however, the deviation from the median in part of 
the analyzed period differs significantly from the deviation in the rest of this period (it is particularly visible for BDZ). Therefore, those three companies were labeled ,ambiguous”.

Table 2. Energy companies classified by their level of debt related to the median level of debt for the analyzed period

\begin{tabular}{|c|c|c|}
\hline Company & $\begin{array}{c}\text { Average deviation of debt ratio value } \\
\text { from the median debt ratio }\end{array}$ & $\begin{array}{c}\text { Classification of the company's debt } \\
\text { ratio in relation to median debt ratio }\end{array}$ \\
\hline IRL & 0.17 & high \\
\hline CEZ & 0.09 & high \\
\hline BDZ & 0.16 & ambiguous \\
\hline ENG & 0.03 & ambiguous \\
\hline PEP & 0.03 & medium \\
\hline ZEP & 0.01 & medium \\
\hline TPE & -0.02 & low \\
\hline ENA & -0.07 & low \\
\hline KGN & -0.13 & low \\
\hline PGE & -0.16 & \\
\hline
\end{tabular}

Source: own calculation based on www1, access 18-31.07.2020.

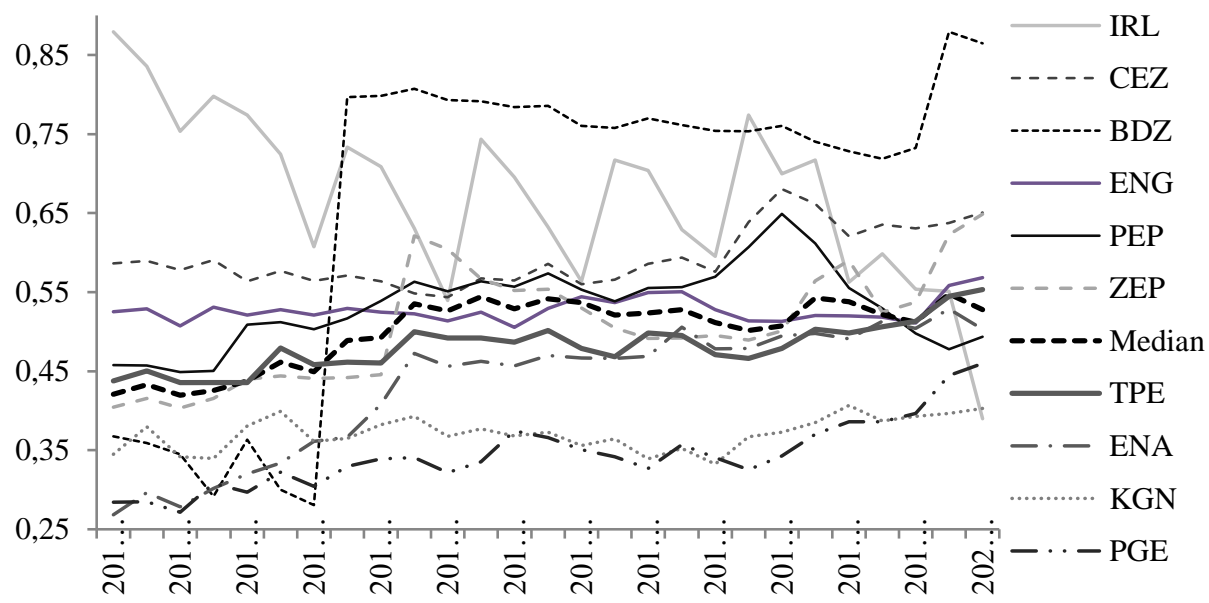

Chart 1. Debt ratio of energy companies and median debt ratio in the analyzed period Source: own work based on www1, access 18-31.07.2020. 
The first part of the research analyzes the correlation (Pearson coefficient) and regression with one exogenous variable (debt ratio). The $\mathrm{R}^{2}$ measure for univariate regression showed that the explanatory power of these estimations is very low. It suggests that there are other important exogenous variables not included in the regression analysis, and the included variable (debt ratio) may partially ,intercept” their impact. For these reasons, multiple regressions are usually analyzed, which is confirmed by the literature review. Therefore, the second part of the research analyzes the multivariate regressions covering two additional exogenous variables that are also probable significant factors that influence the valuation of the company:

- return on assets (ROA); the ability of the company to generate profits from its assets is undoubtedly an important aspect investors consider when making decisions on the capital market; and unlike ROE, ROA is not directly related to the level of financial leverage;

- the overall price to book ratio of the market, i.e., the ratio calculated for all shares quoted on Warsaw Stock Exchange; the overall sentiment on the market can significantly impact the valuation of individual companies, regardless of their financial performance or capital structure.

The inclusion of additional variables in the regression analysis may show whether the strength or statistical significance of the debt ratio in univariate regression analysis results from this variable ,intercepting” the influence of other significant factors.

\section{RESULTS}

The results of the correlation and regression analysis with one exogenous variable (debt ratio) are presented in Table 3.

The results are surprising. The correlation coefficients and regression coefficients are positive for companies with a high debt level and negative for companies with a low debt level. This completely contradicts the expectations that resulted from theoretical premises based on the literature review. The coefficients are also negative for companies with a debt level close to the industry median (they are the only results that are consistent with the expectations) and for the companies defined as ,ambiguous". Moreover, the significance tests (t-stats) show that the debt ratio for most companies is a statistically significant factor that impacts the price to value ratio of companies - only for two of them (Energa and ZEPAK) is the statistical significance of the coefficient's estimation too low. However, the $\mathrm{R}^{2}$ measure shows that the explanatory power of these estimations is very low; therefore, multivariate regression analysis was also performed. The results of this analysis are presented in Table 4. 
Table 3. Correlation and univariate regression analysis

\begin{tabular}{|c|c|c|c|c|c|c|c|c|}
\hline \multirow{2}{*}{$\begin{array}{c}\text { Com- } \\
\text { pany }\end{array}$} & \multirow{2}{*}{$\begin{array}{c}\text { Debt } \\
\text { level } \\
\text { classifi- } \\
\text { cation }\end{array}$} & \multicolumn{2}{|c|}{$\begin{array}{c}\text { Pearson corre- } \\
\text { lation coefficient }\end{array}$} & \multicolumn{6}{|c|}{ Univariate regression } \\
\cline { 5 - 9 } & value & t-stat & value & t-stat & value & t-stat & \multirow{2}{*}{$\mathrm{R}^{2}$} \\
\hline IRL & high & 0.49 & 2.80 & -0.30 & -0.33 & 3.80 & 2.80 & 0.24 \\
\hline CEZ & high & 0.80 & 6.77 & -1.48 & -4.32 & 3.89 & 6.77 & 0.65 \\
\hline BDZ & abiguous & -0.40 & -2.20 & 0.60 & 7.57 & -0.25 & -2.20 & 0.16 \\
\hline ENG & abiguous & -0.09 & -0.47 & 1.37 & 0.80 & -1.52 & -0.47 & 0.01 \\
\hline PEP & abiguous & -0.55 & -3.31 & 2.73 & 4.76 & -3.55 & -3.31 & 0.30 \\
\hline ZEP & medium & -0.07 & -0.36 & 0.27 & 3.26 & -0.06 & -0.36 & 0.01 \\
\hline TPE & medium & -0.80 & -6.56 & 1.77 & 7.90 & -3.05 & -6.56 & 0.63 \\
\hline ENA & low & -0.84 & -7.80 & 0.94 & 13.36 & -1.26 & -7.80 & 0.71 \\
\hline KGN & low & -0.62 & -3.93 & 2.65 & 5.13 & -5.46 & -3.93 & 0.38 \\
\hline PGE & low & -0.86 & -8.46 & 1.69 & 12.29 & -3.34 & -8.46 & 0.74 \\
\hline
\end{tabular}

Source: own calculations based on www1, access 18-31.07.2020 and www2, access 18.07.2020.

Table 4. Multivariate regression analysis

\begin{tabular}{|c|c|c|c|c|c|c|c|c|c|c|}
\hline \multirow{2}{*}{$\begin{array}{c}\text { Com- } \\
\text { pany }\end{array}$} & \multirow{2}{*}{$\begin{array}{c}\text { Debt level } \\
\text { classifi- } \\
\text { cation }\end{array}$} & \multicolumn{2}{|c|}{ intercept } & \multicolumn{2}{c|}{$\begin{array}{c}\text { coefficient for } \\
\text { debt ratio }\end{array}$} & \multicolumn{2}{c|}{$\begin{array}{c}\text { coefficient for } \\
\text { ROA }\end{array}$} & \multicolumn{2}{c|}{$\begin{array}{c}\text { coefficient for } \\
\text { market P/BV }\end{array}$} & \multirow{2}{*}{$\mathrm{R}^{2}$} \\
\cline { 3 - 13 } & value & t-stat & value & t-stat & value & t-stat & value & t-stat & \\
\hline IRL & high & 2.66 & 1.60 & 2.23 & 1.50 & -2.82 & -2.56 & -1.20 & -0.96 & 0.42 \\
\hline CEZ & high & -0.47 & -0.58 & 2.96 & 3.29 & -0.22 & -0.21 & -0.40 & -1.42 & 0.68 \\
\hline BDZ & abiguous & -0.22 & -1.07 & -0.23 & -2.43 & -0.10 & -0.97 & 0.71 & 4.11 & 0.52 \\
\hline ENG & abiguous & -0.34 & -0.19 & 0.69 & 0.21 & 1.43 & 1.60 & 0.44 & 1.00 & 0.20 \\
\hline PEP & abiguous & 4.02 & 4.92 & -3.36 & -3.52 & 0.85 & 0.68 & -1.22 & -2.60 & 0.56 \\
\hline ZEP & medium & -0.02 & -0.15 & 0.22 & 1.51 & 0.11 & 3.36 & 0.13 & 1.56 & 0.40 \\
\hline TPE & medium & 1.18 & 3.76 & -2.61 & -5.40 & -0.09 & -0.51 & 0.33 & 2.68 & 0.72 \\
\hline ENA & low & 0.43 & 3.11 & -1.10 & -8.02 & -0.05 & -0.26 & 0.39 & 4.07 & 0.83 \\
\hline KGN & low & -0.27 & -0.59 & -1.58 & -1.76 & -0.18 & -1.00 & 1.31 & 7.93 & 0.83 \\
\hline PGE & low & 1.57 & 4.84 & -3.28 & -6.79 & -0.06 & -0.35 & 0.08 & 0.45 & 0.74 \\
\hline
\end{tabular}

Source: own calculations based on www1, access 18-31.07.2020 and www2, access 18.07.2020. 
The inclusion of two additional variables in the regression analysis significantly improved the quality of the estimates (the $\mathrm{R}^{2}$ measure values are much higher than for the univariate regressions), which confirms that extending the set of exogenous variables is the right direction of the research. The selection of the variable that represents the overall market price to book value ratio is particularly justified. This variable coefficient is statistically significant for five out of the ten companies. The return on assets proved to be a highly significant variable for only two companies, but the significance of the other two variables for these two companies is low, which suggests that ROA is an important factor in those two cases. Nevertheless, the debt ratio remains a variable with high statistical significance for six out of ten companies. For the next three, the t-stat values do not differ much from the level considered sufficient. Therefore, it should be concluded that the degree of financial leverage is one of the important factors considered by the stock market investors that impact the valuation of the companies they invest in.

As for the direction of the impact, the results again proved surprising and contrary to expectations. For companies with a high level of debt, the impact of debt ratio on the valuation of companies is positive, and for companies with a low debt level, this impact is negative. This means that if a company with a high debt ratio increases it even more, then the value of this company (represented by the price to book value ratio) increases, while if a company with a low starting debt level increases the debt ratio, its price to book value ratio decreases.

Summarizing the results of the research, the hypotheses can be verified as follows:

- the high significance of the correlation coefficients, univariate regression coefficients, and multivariate regression coefficients makes it possible to conclude that there are no grounds to reject hypothesis 1, i.e., the degree of leverage is an important factor that impacts the market valuation of companies;

- the signs of the correlation and regression coefficients estimated in the research for the debt ratio variable are contrary to what was expected; it is the basis for rejecting hypothesis 2 , i.e., for companies with a high level of leverage, the impact of this leverage on their valuation is negative, and for companies with a low level of leverage, the impact is positive.

\section{DISCUSSION}

The conclusions from the literature review did not allow for an unambiguous statement about the direction of the impact of financial leverage on the market valuation of companies. This research confirmed the high statistical significance 
of this impact, but surprisingly, the results regarding the direction of this impact are contrary to the theoretical premises. It seems unreasonable for investors to react negatively to an increase in debt financing by a company that has relatively small debt, and to react positively to an increase in debt by a company that is already significantly leveraged. The results of the research suggest that investors indeed act like this, at least in the case of energy companies listed on the Warsaw Stock Exchange. It is tempting to formulate a hypothesis that matches the results, which seems to be internally consistent and statistically significant, and accept it in place of the rejected hypothesis 2 . However, this cannot be done because there are no theoretical premises for this. Thus, the conclusions must be limited only to stating that hypothesis 2 must be rejected, and the mechanism assumed by this hypothesis has no empirical evidence.

There were some doubts in the study related to the use of the median as an approximation of the optimal level of debt ratio for all companies in the analyzed industry. Ultimately, however, these doubts are irrelevant because the opposite values of the signs of the correlation and regression coefficients were obtained for companies with clearly extreme (highest and lowest) levels of debt, so the conclusions from the research are also justified without referring to the median value.

The results make the problem even more intriguing. In further research, it would be justified to consider other possible mechanisms of the impact of debt ratio on the market valuation of companies. It may also be reasonable to analyze the correlation and regression, taking into account differently defined variables and/or a different set of variables. This study is a good basis to further explore the topic.

\section{CONCLUSIONS}

The study examined the impact of leverage on the market valuation of companies. The literature review does not provide an unequivocal conclusion to the problem; in general, studies show that this impact is statistically significant, but the direction of the impact in some studies proved to be positive, and in others, it was negative. The review made it possible to specify several factors that may influence the relationship between the company's debt and its valuation, like belonging to a given industry, the level of leverage in relation to the optimal capital structure, and factors other than leverage that influence the company's valuation. These conclusions were taken into account while designing the empirical research, which was based on correlation and regression analysis. Classifying the companies into several groups, depending on their level of debt ratio in relation to 
the industry median debt ratio, was an important component of the research, omitted in many previous studies, but, as it turned out, very valid.

The empirical data analysis did not give grounds to reject the first hypothesis; therefore, it can be stated that the degree of leverage is an important factor that impacts the market valuation of companies. The situation is different in the case of the second hypothesis, which states that for companies with a high level of leverage, the impact of this leverage on their valuation is negative, and for companies with a low level of leverage, the impact is positive. This hypothesis was verified negatively (i.e., rejected) because the research showed positive correlation and regression coefficients between the debt ratio and price to book value ratio for highly leveraged companies, and negative ones for companies with a low level of debt.

The results of the study are not in line with the previous works. In spite of the fact that other researchers in theoretical parts of their studies emphasized that there are two opposing mechanisms of the influence of leverage on the company's valuation, the conclusions of their empirical research suggest that they expected a homogeneous (only positive or only negative) impact in each case. This paper takes this aspect into account and shows that the analyzed impact is not homogenous and may depend on how far the level of leverage of particular company deviates from the optimal level, which is a new approach to this subject. Alas, the direction of the impact for companies with clearly extreme (highest and lowest) levels of debt turned out to be exactly opposite to what was expected, which also contradicts the previous research. The discussion contains several suggestions that would be helpful in any further study aiming to explain such surprising results.

\section{BIBLIOGRAPHY}

Acheampong P., Agalega E., Shibu A.K., 2014, The Effect of Financial Leverage and Market Size on Stock Returns on the Ghana Stock Exchange: Evidence from Selected Stocks in the Manufacturing Sector, „International Journal of Financial Research”, vol. 5, no. 1.

Adenugba A.A., Ige A.A., Kesinro, O.R., 2016, Financial Leverage and Firms' Value: A Study of Selected Firms in Nigeria, „European Journal of Research and Reflection in Management Sciences", vol. 4, no. 1.

Dita A.H., Murtaqi I., 2014, The Effect of Net Profit Margin, Price To Book Value and Debt To Equity Ratio to Stock Return in the Indonesian Consumer Goods Industry, „Journal Of Business And Management", vol. 3, no. 3.

Gill A., Obradovich J., 2012, The Impact of Corporate Governance and Financial Leverage on the Value of American Firms, „International Research Journal of Finance and Economics”, issue 91.

Hatfield G.B., Cheng L.T.W., Davidson W.N., 1994, The Determination of Optimal Capital Structure: The Effect of Firm and Industry Debt Ratios on Market Value, „Journal Of Financial And Strategic Decisions", vol. 7, no. 3. 
Hirdinis M., 2019, Capital Structure and Firm Size on Firm Value Moderated by Profitability, „International Journal of Economics and Business Administration”, vol. VII, issue 1.

Hodgson A., Stevenson-Clarke P., 2000, Accounting Variables and Stock Returns: The Impact of Leverage, „Pacific Accounting Review”, vol. 12, no. 2.

Ibrahim U.A., Isiaka A.Q., 2020, Effect of Financial Leverage on Firm Value: Evidence From Selected Firms Quoted on the Nigerian Stock Exchange, ,European Journal of Business and Management", vol. 12, no. 3.

Jao R., Hamzah D., Laba A.R., Mediaty, 2020, Investor Decision in Estimating the Effect of Earning Persistence, Financial Leverage, Foreign Ownership Toward Company Reputation and Company Value, „International Journal of Financial Research”, vol. 11, no. 4.

Lestari E.P., Astuti D., Basir M.A., 2020, The role of internal factors in determining the firm value in Indonesia, ,Accounting”, no. 6.

Łukasik G., Naczyński D., 2015, Rola struktury kapitalu w ksztaltowaniu wartości przedsiębiorstwa (elementy teorii, doświadczenia praktyki) (The Role of Capital Structure Management (Elements of the Theory, Experience, Practice)), „Zeszyty Naukowe Szkoły Głównej Gospodarstwa Wiejskiego. Ekonomika i Organizacja Gospodarki Żywnościowej”, nr 112.

Marlina T., 2013, Pengaruh Earning Per Share, Return On Equity, Debt To Equity Ratio dan Size Terhadap Price To Book Value, „Jurnal Ilmiah Akuntansi Kesatuan”, no. 1(1).

Modigliani F., Miller M.H., 1958, The Cost of Capital, Corporation Finance, and the Theory of Investment, „The American Economic Review”, vol. 48, no. 3.

Muradoglu G., Sivaprasad S., 2008, An Empirical Test on Leverage and Stock Returns, Working Paper Series, Cass Business School, London.

Nissim D., Penman S.H., 2003, Financial Statement Analysis of Leverage and How It Informs About Profitability and Price-to-Book Ratios, „Review of Accounting Studies”, vol. 8.

Pandya B., 2016, Impact of Financial Leverage on Market Value Added: Empirical Evidence from India, ,Journal of Entrepreneurship, Business and Economics”, vol. 4(2).

PeiZhi W., Ramzan M., 2020, Do corporate governance structure and capital structure matter for the performance of the firms? An empirical testing with the contemplation of outliers, „PLoS ONE", no. 15(2): e0229157, https://doi.org/10.1371/journal.pone.0229157 [access 11.12.2020].

Rizqia D.A., Aisjah S., Sumiati, 2013, Effect of Managerial Ownership, Financial Leverage, Profitability, Firm Size and Investment Opportunity on Dividend Policy and Firm Value, „Research Journal of Finance and Accounting”, vol. 4, no. 11.

Singh A.K., Bansal P., 2016, Impact of Financial Leverage on Firm's Performance and Valuation: A Panel Data Analysis, ,Indian Journal of Accounting”, vol. XLVIII(2).

[www1] www.biznesradar.pl [access 18-31.07.2020].

[www2] www.stooq.pl [access 18.07.2020]. 